\title{
Water security in South Africa: perceptions on public expectations and municipal obligations, governance and water re-use
}

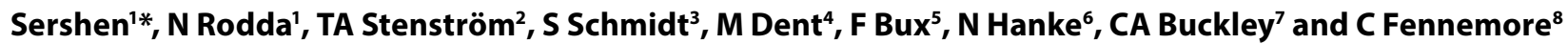 \\ ${ }^{1}$ School of Life Sciences, University of KwaZulu-Natal, Westville Campus, Durban, South Africa \\ ${ }_{2}^{2}$ SARChI Chairholder, Institute for Water and Wastewater Technology, Durban University of Technology, Institute for Water and Wastewater Technology, \\ Durban, South Africa \\ ${ }^{3}$ School of Life Sciences, University of KwaZulu-Natal, Pietermaritzburg Campus, Pietermaritzburg, South Africa \\ ${ }^{4}$ School of Agriculture, Earth and Environmental Sciences, University of KwaZulu-Natal, Pietermaritzburg Campus, Pietermaritzburg, South Africa \\ 5 Institute for Water and Wastewater Technology, Durban University of Technology, Durban, South Africa \\ ${ }^{6}$ Stellenbosch University Water Institute (SUWI), Cape Town, South Africa \\ 'Pollution Research Group, University of KwaZulu-Natal, Durban, South Africa \\ ${ }^{8}$ eThekwini Water \& Sanitation, eThekwini Municipality, Durban, South Africa
}

\begin{abstract}
South Africa is a water-scarce country with increasing pressure on its water resources. Urgent interventions are needed to protect water security within this rapidly developing country. This paper reports on an interdisciplinary Water Security Colloquium, convened by the South African Young Academy of Science in 2014. A selected group of water professionals from academia, civil society and local government was brought together to discuss water security under three focus themes: 'public expectations and municipal obligations', 'water security and governance: challenges and advances', and 'water re-use: health and infrastructural considerations'. Participant perceptions were generated using a focus group methodology, combined with participatory data collection methods. Under each theme, inputs were categorised as 'challenges', 'gaps in knowledge', and 'solutions/recommendations' and these inputs were thereafter ranked in order of importance via a 'voting' process. Major challenges perceived included a lack of both skills and political will in government, a need to restore citizen trust in government intention and capability to deliver water-related services, and a failure to up-scale existing water re-use technology. Participants identified understanding of the process and implications of the Green and Blue Drop Programmes, knowledge transfer to the public, and the role of educators as major knowledge gaps. The top suggestions proposed included creating public awareness around and buy-in to initiatives to improve water security, accessible and user-friendly conversion of research results to implementation, and ensuring an active role for educators in creating awareness around water security. In view of the concerns identified, participants suggested as potential solutions: improving government and public understanding around water issues, incentivising water re-use and conservation, introducing rising block tariffs and improving human capacity development in the water sector. Developing the ecological infrastructure that protects both quantity and quality of water and building strong partnerships among all stakeholders were also recognised as key.
\end{abstract}

Keywords: capacity development, education, governance, water security, water re-use, water conservation, local government

\section{INTRODUCTION}

Since water is a source of life and livelihoods, access to safe drinking water is regarded as a basic human right and a symbol of dignity that recognises the inherent value and importance of every human being (Hardberger, 2005 and references therein). This may explain why the term 'water security' has in recent times come to feature in so many civil society, governmental and academic discourses on socio-economic development. Despite its frequency of use though, the term lacks, and requires, clear definition. In contrast, the terms 'food security' and 'energy security' are now widely accepted to mean, 'reliable access to sufficient supplies of food or energy, respectively, to meet basic needs of individuals, societies, nations or groups of nations, thus supporting lives, livelihoods and production' (Grey and Sadoff, 2007 p. 547]). The term 'water security' has hence been likened in the literature to an equivalent meaning, but a striking difference is that water, unlike food or energy, can represent a threat

\footnotetext{
* To whom all correspondence should be addressed.

- e-mail: naidoose@ukzn.ac.za

Received 5 August 2015; accepted in revised form 3 June 2016
}

in both its absence and presence. For the purposes of this article, we define 'water security' in terms of the definition provided by Grey and Sadoff (2007 p. 545): 'the availability of an acceptable quantity and quality of water for health, livelihoods, ecosystems and production, coupled with an acceptable level of water-related risks to people, environments and economies.'

The Millennium Development Goals (MDGs), now superseded by the Sustainable Development Goals (SDGs) (Weitz et al., 2014), included Goal 7, which embodied the need to ensure environmental sustainability. Goal 7 challenged the world to halve, by 2015, the proportion of people lacking sustainable access to safe drinking water and basic sanitation (UNICEF and WHO, 2015). Vörösmarty et al. (2010) showed that, despite this call for increased access to safe drinking water, in 2010 nearly $80 \%$ of the world's population were exposed to high levels of water insecurity, regarded as the antipodal to water security While massive investment in water technology has enabled wealthy nations to offset high stressor levels over the past two decades without remedying their underlying causes, poorer nations remain vulnerable (UNICEF and WHO, 2015). This is particularly true in Africa, where many regions (particularly rural areas) still display the lowest water supply coverage globally (Heijnen et al., 2014; UNICEF and WHO, 2015). In 2015, 
it was estimated that half of the 663 million people worldwide that continue to use unimproved drinking water sources reside in sub-Saharan Africa (UNICEF and WHO, 2015). Of even greater concern is the fact that diseases associated with poor water and sanitation continue to pose a significant risk to public health in the developing world (Fink et al., 2011; UNICEF and WHO, 2015). In many parts of Africa, the solution appears to be as simple as increasing the rate at which access to improved water and sanitation is extended but achieving this appears to be far from simple; ecological, social, financial, political and more recently climate change related challenges abound (UNICEF and WHO, 2015).

A myriad of studies have interrogated Africa's water and sanitation problems over the past two decades (Collignon and Vézina, 2000; Vörösmarty et al., 2005; Siebrits et al., 2014; Valipour, 2015) and researchers from disciplines as far ranging as geopolitics (Heijnen et al., 2014; Valipour, 2015) and microbiology (Nyenje et al., 2010) have tried to identify the challenges and potential solutions. However, very few of these studies (e.g. Siebrits et al., 2014) have attempted to bring together the various water sector roleplayers to identify common and unique challenges, gaps in knowledge, and recommendations in relation to water security. This gap in the current research agenda motivated the present study. The study analyses the perceptions of selected government, private, academic and civil society, water and sanitation experts and practitioners from various South African municipalities, of some of the socio-economic, environmental and political factors influencing water security in one of Africa's most influential and geographically and socio-economically diverse countries.

For the sake of context, South Africa is a largely semiarid water-stressed country, with an average annual rainfall of approximately $464 \mathrm{~mm}$ compared with a world average of $860 \mathrm{~mm}$ (WESSA, 2012). The country has built many dam systems; however, water resources within these dams and rivers are highly threatened by the presence of alien plants, sandmining activities, industrial effluent discharge, high evaporative rates and a number of other factors (Coetzee et al., 2010). Additionally, due to rural-urban migration, as in other parts of Africa there has also been a dramatic increase in urban dwellers mainly living in poorly or un-serviced slums which has had negative implications (in terms of quantity and quality) on natural resources such as river water (DWAF, 2005; Nyenje et al., 2010; UNICEF and WHO, 2015). In terms of access to water, South Africa's 2011 Census (Statistics South Africa, 2012) revealed that $46.3 \%$ of households in South Africa have access to piped water and slightly over $85 \%$ have access to water that is of a Reconstruction and Development Programme (RDP)-acceptable level. However, these levels of access are not reflected across all provinces. In the Eastern Cape and Limpopo, for example, $31 \%$ and $27.2 \%$ of households have no access to water of RDPacceptable level, respectively.

The impacts of pollution and the state of bulk water and wastewater infrastructure represent serious concerns in South Africa (HRC, 2014). The rivers in the lower-lying northern regions of the country are reported to be mainly polluted by acid mine drainage from mining activities in the area and electricity production (Coetzee et al., 2010; Pheiffer et al., 2014). Surface water quality in many parts of the country is also threatened by excessive nutrient inflow, mainly from domestic effluent (untreated wastewater) and industrial and sewage effluent (treated wastewater from sewage treatment works), run-off from agricultural lands and uncontrolled disposal of wastewater from informal settlements (reviewed by Nyenje et al.,
2010). A 2011 report by the South African Institute for Civil Engineering (SAICE) and the Centre for Scientific and Industrial Research (CSIR) suggests that much of South Africa's bulk water infrastructure will soon require upgrade or replacement as a consequence of reaching the end of its lifespan (SAICE, 2011). The report goes on to state that 'a serious problem regarding bulk infrastructure is uncontrolled, high levels of pollution, especially in dams. Mingling pollutants near urban areas makes identification and penalisation of the many offenders extremely difficult.' The Department of Water and Sanitation (DWS, previously DWAF), together with the associated water providers, are responsible for the maintenance of fresh and drinking water standards across South Africa (DWA, 2013a, 2013b). The major challenge of the South African Government in recent times has been to develop and maintain appropriate policies to protect South African freshwater resources. The extent to which the various municipalities comply with these standards and with international and South African water law is also monitored regularly (DWA, 2010) using two monitoring and evaluation tools: the Green Drop Programme which reports on the integrity of treated effluent released from wastewater treatment works into rivers and the sea (DWA, 2013a), and the Blue Drop Programme which assesses the quality of potable water (DWA, 2013b).

The present study arose out of the urgent need to address water security in the South African context and to stimulate dialogue among academia, civil society and government around factors impacting on water security in the country (Siebrits et al., 2014). The focus group discussions and other participatory methods employed to generate participant perceptions on these factors were conducted during The South African Young Academy of Science's (SAYAS) interdisciplinary colloquium on Water Security in South Africa. The colloquium, held at the University of KwaZulu-Natal (Durban) on 25 and 26 June 2014, was specifically designed to investigate expert and practitioner perceptions of water security in South Africa for the following thematic areas:

- Public expectations and municipal obligations

- Water security and governance: challenges and advances

- Water re-use: health and infrastructural considerations

The data presented and conclusions drawn add to the growing body of knowledge on the threats and approaches to water security in Africa. Most importantly, the challenges and knowledge gaps identified and recommendations made by the participants can potentially help inform the design of local and national water strategies within South Africa.

\section{METHODOLOGY}

\section{Focus group discussions}

This study adopted a classical focus group methodology, combined with participatory data collection methods (Powell and Single, 1996). The focus group comprised 56 experts and practitioners in the fields of water and/or sanitation from various parts of South Africa. Care was taken to include individuals from the government, private, academic and civil society sectors. This was achieved by inviting all individuals and organisations on the South African Water Research Commission (WRC), the South African Local Government Association (SALGA), the Academy of Science of South Africa (ASSAF), the South African Young Water Professionals (YWP) and the SAYAS Listserve. 
Semi-structured interviews $(n=10)$ with water and sanitation experts were conducted prior to the colloquium to establish the key factors influencing water security in South Africa. These factors, which included governance, public expectations, municipal obligations and water re-use amongst others, informed the design of thematic areas to be addressed at the colloquium. The focus group adopted guided, interactional discussion as a means of generating information on experiences and the reasoning behind participant actions, beliefs, perceptions and attitudes (Powell and Single, 1996) around the topic of water security in South Africa. At the start of each thematic session (viz. (1) public expectations and municipal obligations regarding water quality; (2) water security and governance: challenges and advances; (3) water re-use: health and infrastructural considerations in view of diversified water resources and the need for water use efficacy), the facilitators were given time to frame/contextualise each theme, drawing on selected literature, to keep the discussion that followed focused. The facilitators then carefully directed an open discussion on the respective theme, with the intention of identifying the challenges, gaps in knowledge, and specific solutions/recommendations related to the theme. This discussion contextualised ideas behind water scarcity, water re-use in view of consumer safety, water quality, climate change adaptation and mitigation, governance, health, food security, urbanisation and rural livelihood strategies.

\section{Data collection and analysis}

Each of the thematic sessions featured a discussion board (located at the front of the venue, in full view of all participants) separated into 3 categories: (i) challenges, (ii) gaps in knowledge, and (iii) solutions/recommendations. During the course of each thematic session the facilitators captured perceptions that emerged during the discussions that ensued and assigned these to the relevant category on the discussion board. At the end of each thematic session, the discussion board was digitized and participants were asked to indicate which perceptions within each category they considered to be the most important/relevant by 'voting, and thus ranking priorities. Participants were allowed to make multiple selections within each category but could not select individual perceptions multiple times. Participants were also given the option of abstaining from voting if they wished to do so. The data were then translated into frequencies (equivalent to the number of 'votes'), which were in turn used to rank the perceptions associated with each theme in decreasing order of importance/relevance, within categories.

\section{RESULTS AND DISCUSSION}

\section{Theme 1: Public expectations and municipal obligations regarding water quality}

\section{Challenges and knowledge gaps}

The White Paper on a National Water Policy for South Africa and embedded documents assign the responsibility for the provision of water services, and the setting of tariffs, to local government (DWAF, 1997). Furthermore, the Water Services Act (Act No. 108 of 1997; RSA, 1997) sets out the regulatory framework for institutions responsible for supplying water services and makes provision for the establishment of different water services institutions. These include: (i) the water services authority - i.e. the responsible municipality and, (ii) the water services provider
- whose role it is to physically supply water and sanitation services to consumers. The vast majority of participants agreed with the view that many municipalities, in serving as water services authorities, were attempting to fulfil their duty to customers or potential customers in their respective areas of jurisdiction in terms of ensuring efficient, affordable and sustainable access to water services. However, the participants were in agreement that the numerous service delivery protests around the country point to service delivery inequalities and the common challenges faced by many municipalities (Table 1), the most serious of which according to the participants are:

- Incapacity of decision-makers and skills deficits within the water sector

- Unrealistic political promises vs. expectations vs. reality (in relation to finance and infrastructure)

\section{- Dysfunctional infrastructure}

The South African Government introduced the Green Drop Certification Programme to monitor the quality of water released from wastewater treatment works into rivers. The Programme is designed to assess all the systems at wastewater treatment works, from budgeting through asset management, staffing, operation, to impact on the environment, with regard to the capacity of a particular wastewater treatment works to consistently deliver effluent which complies with the discharge limits of that works (Day et al., 2011). Discharge limits are based on general limits set in the Water Services Act (1997), balanced against various factors including the volume discharged and the quality of the receiving water body. Similarly, the Blue Drop Certification Programme is a means to monitor the quality of potable water produced and the capacity to deliver that quality consistently (DWA, 2013b). The Blue Drop reports are based on the widely accepted notion that the quality of drinking water produced by a drinking water treatment plant is a function of technology and the human skill to maintain and control the technology and unit processes. Based on this, the results of the DWA's 2013 Blue Drop progress report (DWA, 2013c) resonate with the perceptions expressed by the participants in terms of the following: (i) with regards to microbiological water quality, only $25 \%$ of the systems reported a compliance of $95 \%$ and better at a monitoring frequency of $80 \%$ and better; (ii) in terms of chemical quality compliance, only 767 of the system/bulk supplier points (72\%) recorded a quality compliance of $95 \%$ and better; and (iii) only $21 \%$ of the systems had the required number of compliant supervisors employed while $66 \%$ of the systems operated without suitably qualified supervisors. Furthermore, the report stated that only $30 \%$ of the systems operated at more than $75 \%$ of design capacity.

Despite the critical issues mentioned above, in 2013 only $13 \%$ of the water treatment systems had active water safety planning processes in place (DWA, 2013c), with an alarming 52\% of systems having no water safety planning activities in place. Based on the participants' perceptions, this lack of prioritisation and planning around water safety in the country may be the product of the following 'challenges' (Table 1):

- Difficulty in balancing public rights and obligations vs. responsibilities

- Diffused roles and responsibilities of local government

- Incapacity of courts/legal system to adjudicate

- Illegal connections

- Inadequate prioritisation of water security 
Other challenges identified to be of relatively lesser importance than those listed above, ranged from non-payment for services to political issues and challenges of rapid urbanisation. In general though, all the challenges identified by participants within this theme spoke to the importance of regulating access to water services in an equitable manner, taking into account technological, socio-economic and ecological implications.

Despite the time that has passed since the 2008 implementation of the Green and Blue Drop Programmes, a number of the participants identified aspects of these programmes to represent the most significant knowledge gap within the sector. When this was probed further, it emerged that, whilst participants were aware of the necessity for the programme, many were uncertain about the following regarding the programme: (i) municipal obligations; (ii) risk-monitoring activities; and (iii) implications of compliance/non-compliance. This suggests that information on the specific requirements for, and implications of, compliance in terms of water safety may not be filtering down to all stakeholders. This raises concerns, especially when one considers the DWA's 2013 finding that risk programmes of just $9 \%$ of the systems across the country are informed by full SANS 241 (SABS, 2006) analysis and risk-defined monitoring programmes. Since compliance processes form the basis of any institutional risk management programme, it is not surprising that the participants perceived an absence or poor performance of water risk management within the country. Other knowledge gaps identified to be important within this theme included issues around the creation and management of knowledge, communication of best practices, legal implications of service provision, and the human factor - human behaviour.

\section{Potential solutions and recommendations}

The top six 'solutions/recommendations' identified by participants included the following as reflected in Table 1:

- Public buy-in and awareness

- Government awareness

- Human capacity building

- Promote water re-use and water conservation

- Good governance

- Ecological infrastructure approach

Whilst it was encouraging to note that participants supported the re-use of wastewater and harnessing the potential benefits of ecological infrastructure, they voiced their concerns by calling for improved public and government awareness, increased human capacity and good governance within the water sector. Increased investment in operations and maintenance was also recommended whilst many of the remaining recommendations, perceived to be relatively less important than those listed above, were more specific suggestions on how awareness, water re-use and infrastructure development could be improved (refer to Table 1).

\section{Theme 2: Water security and governance: challenges and advances}

\section{Challenges and knowledge gaps}

Issues around governance and water security currently feature in many debates across a number of sectors within the country and the continent as a whole. The initial discussions under this theme revealed that different stakeholder groups generally have different perspectives on water-related risk and that, for this reason, a diversity of perspectives is vital to ensure water security. Participants stressed that transparency and committed connection to the water dialogue by all stakeholders is imperative if the socially-robust knowledge required for wise stewardship is going to be generated. In the discussions that ensued it was generally agreed that the governance framework in South Africa is conducive to poly-centric, multi-stakeholder engagement to address water security effectively, but that the uptake of opportunities by stakeholders is unacceptably slow.

The need to restore citizen trust and increase transparency topped the list of challenges (Table 2). According to Buytaert et al. (2014), the quest for transparency that helps to build trust forms a key element of the motivational forces in the rise of citizen science which is defined as 'the systematic collection and analysis of data; development of technology; testing of natural phenomena; and the dissemination of these activities by researchers on a primarily avocational basis' (Open Scientist, 2011 p.1). Inherent in many citizen science endeavours is the use of the Internet to connect people, share and create knowledge and increase awareness around sustainable development. For example, the participants learnt how residents belonging to the Palmiet River Watch Programme (based in Westville, Durban, KwaZulu-Natal) actively collect and share information (with each other and the municipality) on water quality in the Palmiet River using a WhatsApp Group (Lee D'Eathe, 2014). It is interesting to note how this need for connectivity in securing water resources leads on to provide insights into some of the other key challenges identified by the participants, namely:

- The skills gap/lack of technical capacity within the water sector

- The need to balance land and water reform

- Knowledge loss (experts leaving country/sector)

- Silo thinking and planning

Many of these challenges may be addressed by tapping into the insights of Dent (2012), Buytaert et al. (2014), Wals et al. (2014) and Scharmer (2009). All the aforementioned stress the value of poly-centric knowledge co-generation in dynamic connected systems as being foundational to learning for sustainable development. In addition to creating a healthier learning environment, the authors all concur that co-generation of knowledge is critical in addressing the skills and finance challenges threatening water security in South Africa. The co-generation of socially-robust knowledge (also known as actionable knowledge) is crucial for implementation of South Africa's water policies. Socially-robust knowledge as defined by Nowotny et al. (2001) is, the product of intensive (and continuous) interaction between results and interpretation, people and environments, applications and implications.'

Reflection on the top two knowledge gaps identified by participants reveals that the need for co-learning came through strongly once again (Table 2). This need was expressed as follows:

- How to ensure an active role of educators

- Consequences of water insecurity

It is interesting to make the connection between these knowledge gaps and a key theme of participatory agent-based social simulation modelling which emerged at various points 
TABLE 1

Ranking of challenges, knowledge gaps and solutions/recommendations relating to public expectations and municipal obligations regarding water quality by colloquium participants; listed in decreasing order of importance

\section{Challenges}

Incapacity of decision-makers and skills deficit within water sector

Unrealistic political promises vs. expectations vs. reality (finance and infrastructure)

Dysfunctional infrastructure

Balance between public rights and obligations vs. responsibilities

Diffused roles and responsibilities of Local Government

Capacity of courts/legal system to adjudicate

Illegal connections

Inadequate prioritisation of water security

Non-payment for services

Research gaps

Using technical solutions to solve political issues

Political issues associated with service provision

Rapid urbanisation

Socio-economic implications of lack of service provision

Influence of climate change on water availability

\section{Knowledge gaps}

Blue Drop/Green Drop Certification Programme

Knowledge creation and management

What informs human choices

Communication of best practices

Legal implications of service provision

Water availability vs. accessibility

Challenges of uncertainty (demands, expectations, cultural stigmas)

Behavioural change with regards to water use

Groundwater quantity and quality

Industrial cost of compliance vs. infringement penalties

Hydrological cycle

Big users of water

\section{Solutions/recommendations}

Public buy-in and awareness

Government awareness

Human capacity building

Promote re-use of wastewater

Good governance

Ecological infrastructure approach

Investment in operations and maintenance

Use of ocean water to flush toilets

Knowledge sharing across local government

School education programmes

Creation of more wetlands

Holistic understanding of complexities of water security

A more people-centred approach to water management

Improved water technologies in agricultural production

Provide basic service with allowance for user upgrade

Improved monitoring and evaluation of water quality and use

Frequency*

15

10

7

5

*Values represent frequencies; $n=56$, multiple responses allowed but participants could abstain from 'voting'

during the focus group discussion. The link can be explained as follows: one of the imperatives in any learning system is that those undergoing the learning need to experience the consequences of their actions. The question then for educators is: 'how may learners be immersed in a context where they can experience the consequences of their actions?' Clearly this is challenging to achieve in the real world of water. However, it is possible in the virtual world of simulation modelling in which others take up roles of conflicting stakeholders competing for and polluting the same common resource. This points to the emerging use of 'serious games' (Wein and Labiosa, 2013) as a teaching aid for education and public awareness around water security.

\section{Potential solutions and recommendations}

The top six solutions/recommendations identified by participants included the following: 
- Empowering educators

- Informed decision-making

- Citizen empowerment

- Academia focussing on applied research

- Educating local government councillors

- Integration of strategic mandates

The participants suggested that in addition to educating citizens, educators and stakeholders involved in governing water security, especially in the light of water conservation and re-use, many of the issues identified could be addressed in micro-worlds that form serious simulation games (Dent, 2012). The science and practice of developing 'serious games' has evolved substantially in the past decade (Wein and Labiosa, 2013), to the point where micro-world simulation games can be relatively quickly tailored to real situations. Educators, citizen groups, businesses and local government officials that make up catchment stakeholder bodies can thus be empowered to explore options and surface assumptions about biophysical and socio-economic relationships in dynamic and complex settings in an environment that is relatively non-threatening. Many of the participants also strongly recommended that academia should focus more on applied research and integration of strategic mandates.

\section{Theme 3: Water re-use - health and infrastructural considerations}

\section{Challenges and knowledge gaps}

The recent United Nations Environment Programme/WHO Environment Outlook Report for Africa ((UNEP/WHO, 2013) highlights that for South Africa, access to renewable water is limited to $\leq 1000 \mathrm{~m}^{3}$ per annum, per capita, which classifies the country as water-stressed. The total water footprint (the amount of fresh water utilised in the production or supply of goods and services used by a person) was in a range of 1 200-1 $385 \mathrm{~m}^{3}$ per year, per capita for the period 1996-2005 for South Africa (Hoekstra and Mekonnen, 2012). Hence, South Africa as a water-stressed country is facing serious challenges due to an unsustainable water consumption pattern based on current water use practices (UNEP/WHO, 2013). The participants identified scaling-up re-use technology, lack of public trust and government transparency, and poor public awareness and knowledge transfer (e.g. from pilot studies) as some of the major challenges to efficient and widespread water re-use in South Africa (Table 3). This may also explain why the participants perceived knowledge transfer to the public, scaling-up water re-use technology and technical solutions for water re-use to represent some of the most important knowledge gaps under the theme. Cultural considerations and political will were also identified as relevant challenges whilst participants identified concerns around biological aspects of water security, such as antibiotics, pathogens, and waterborne diseases, to represent significant knowledge gaps.

Water re-use in both rural and urban environments is an essential strategy to overcome the looming water scarcity in South Africa (Ghunmi et al., 2011; Rodda et al., 2011); however, the data presented in Table 3 suggest that information on water re-use may not be filtering down to the public. Public awareness around water re-use and its necessity is essential since the threat of water insecurity is further complicated by the interdependency between water, energy and food production and

\begin{tabular}{|c|c|}
\hline \multicolumn{2}{|c|}{$\begin{array}{l}\text { TABLE } 2 \\
\text { Ranking of challenges, knowledge gaps and solutions/rec- } \\
\text { ommendations relating to water security and governance- } \\
\text { challenges and advances by colloquium participants; listed } \\
\text { in decreasing order of importance }\end{array}$} \\
\hline Challenges & Frequency* \\
\hline Restoring citizen trust & 7 \\
\hline Lack of transparency & 6 \\
\hline $\begin{array}{l}\text { Skills gap/lack of technical capacity within the water } \\
\text { sector }\end{array}$ & 6 \\
\hline Finding the balance between land and water reform & 5 \\
\hline Knowledge loss (experts leaving country/sector) & 4 \\
\hline Silo thinking and planning & 4 \\
\hline Translating research to policy & 4 \\
\hline Stakeholder engagement & 3 \\
\hline Business model for consultancy services & 2 \\
\hline \multicolumn{2}{|l|}{ Knowledge gaps } \\
\hline How to ensure an active role of educators & 10 \\
\hline Consequences of water insecurity & 10 \\
\hline Methods and avenues for knowledge dissemination & 4 \\
\hline Participatory agency-based social simulation & 2 \\
\hline Impact of systemic risk & 2 \\
\hline Enabling governance systems & 2 \\
\hline Conflict management & 2 \\
\hline Truncated terms of reference & 1 \\
\hline \multicolumn{2}{|l|}{ Solutions/recommendations } \\
\hline Empowering educators & 6 \\
\hline Informed decision-making & 6 \\
\hline Citizen empowerment & 6 \\
\hline Academia should focus on applied research & 5 \\
\hline Educate local government councillors & 4 \\
\hline Integration of strategic mandates & 4 \\
\hline Environmental education & 3 \\
\hline Ensure stakeholder analysis and participation & 3 \\
\hline Develop mechanisms to manage conflicts & 2 \\
\hline Connect knowledge champions & 1 \\
\hline Understand social implications of water insecurity & 1 \\
\hline Promote inter-sectoral planning & 1 \\
\hline Improve leadership & 1 \\
\hline
\end{tabular}

${ }^{*}$ Values represent frequencies; $n=56$, multiple responses allowed but participants could abstain from 'voting'.

consumption. This means that the resource scarcity of safe water will directly hamper its affordability and accessibility, especially for the most vulnerable members of society. To envision ways forward it is thus important to identify the main drivers of water consumption in South Africa. Like many other countries with a thriving agricultural sector, the production of agricultural goods contributed approximately $69 \%$ per year, per capita, to the South African water footprint for the period 1997-2001, while the corresponding figures for industrial goods and domestic consumption amounted to $\pm 3 \%$ and $\pm 6 \%$, respectively (Hoekstra and Chapagain, 2007). This consumption pattern is similar to other rapidly developing countries (Hoekstra and Chapagain, 2007). Given the still increasing population in Africa (Gerland et al., 2014) and concomitant urbanisation, it is clear that the demand for water, energy and food will be increasing further. This highlights the importance of a combination of water conservation and water re-use as a means to reduce water consumption related to agricultural, industrial, and domestic consumption. 


\section{Possible solutions and recommendations}

Participants acknowledged that the re-use of water in agricultural production and for domestic or other purposes could only be considered as a feasible option if the safety and health of consumers is guaranteed. This is applicable to all potential sources such as lakes and rivers, harvested rainwater, greywater or treated and untreated wastewater. Participants encouraged user-friendly knowledge transfer (research to application) and public education around re-use and suggested that rainwater harvesting and shared ownership of infrastructure be promoted (Table 3). This necessitates an understanding of the relationship between re-use and sanitation practices which may include monitoring of the microbiological and chemical water quality prior to re-use and the transparent communication and dissemination of monitoring results to enable public buy-in. The quality of water for re-use can be based on the risk-based management criteria stipulated by international bodies such as the WHO or national governments. For example, the risk-based framework in the Sanitation Safety Planning Manual (WHO, 2015) provides a step-by-step management plan for safe re-use and disposal of wastewater, greywater and excreta, as is intended by the Blue and Green Drop process in South Africa. However, the participants raised the point that many water sources intended for re-use might pose major health risks due to the presence of microbiological (e.g. pathogenic viruses, bacteria or parasites) or chemical contaminants (pharmaceuticals, endocrine disruptors, antibiotics). Many of these contaminants have been found in South African rivers, such as the Msunduzi and uMngeni Rivers in KwaZulu-Natal, that serve as potential water sources for peri-urban communities and are subject to effluent inflow (Gemmell and Schmidt, 2013; Matongo et al., 2015). Information on the contaminant burden for potential water re-use sources is presently limited for South Africa but the potential re-use risks appear to be linked to technical solutions such as the ability to treat such water at a larger scale to safeguard sufficient water quality. The up-scaling of pilot studies to production scale is therefore a way forward in closing knowledge gaps identified by participants, enabling technology transfer and increasing the public awareness via a transparent communication process (Table 3).

The participants also identified horizontal wetlands (i.e. soil filters with plants present that are exposed to horizontallyflowing polluted water to bring about pollutant removal), greywater flush toilets, and on-site pre-treatment, amongst other possible options, to be worthwhile technological interventions and encouraged the formation of innovation hubs to develop re-use technology (Table 3). In this regard, potential technical solutions to establish safe re-use of water in different application scenarios - from micro-drip irrigation to reverse osmosis - are available but need to be adapted to meet local requirements and might require approaches such as shared ownership to enable their establishment. Harvesting rainwater is a well-established and simple way to provide water to rural and urban households and can be effective when coupled with simple on-site treatment systems (e.g. sand filters or thermal and radiation treatment fuelled by solar energy). For leafy vegetables that are minimally processed, overhead irrigation re-using river or wastewater as practised by rural communities and peri-urban small-scale farmers in South Africa poses an unacceptable health risk for consumers in case of faecal pollution. However, this can be mitigated by using drip irrigation or subsurface systems, ideally developed to be affordable, robust and fuelled by solar energy, or by enabling on-site pre-treatment of such water to meet safe irrigation requirements stipulated by the responsible governing bodies. In

\begin{tabular}{|c|c|}
\hline \multicolumn{2}{|c|}{$\begin{array}{l}\text { TABLE } 3 \\
\text { Ranking of challenges, knowledge gaps and solutions/rec- } \\
\text { ommendations relating to water re-use health and infra- } \\
\text { structural considerations by colloquium participants; listed } \\
\text { in decreasing order of importance }\end{array}$} \\
\hline Challenges & Frequency* \\
\hline Scaling-up re-use technology & 11 \\
\hline Lack of public trust and government transparency & 9 \\
\hline Diffusion of learning from pilot studies & 7 \\
\hline Public awareness and knowledge & 7 \\
\hline Cultural considerations & 6 \\
\hline Political will & 5 \\
\hline Social implications of re-use & 2 \\
\hline Start-up costs & 1 \\
\hline \multicolumn{2}{|l|}{ Knowledge gaps } \\
\hline Knowledge transference to public & 14 \\
\hline Scaling-up water re-use technology & 12 \\
\hline Technical solutions for re-use & 12 \\
\hline Antibiotic risks & 7 \\
\hline Pathogens and diseases & 5 \\
\hline \multicolumn{2}{|l|}{ Solutions/recommendations } \\
\hline $\begin{array}{l}\text { User-friendly knowledge transfer (research to } \\
\text { application) }\end{array}$ & 10 \\
\hline Incentivise water re-use & 7 \\
\hline Public education (multi-media) & 7 \\
\hline Promote rainwater harvesting & 6 \\
\hline Encourage shared ownership of infrastructure & 6 \\
\hline Horizontal wetlands and filtration & 2 \\
\hline Greywater flush toilets & 2 \\
\hline On-site pre-treatment & 2 \\
\hline Innovation hubs to develop re-use technology & 2 \\
\hline
\end{tabular}

${ }^{*}$ Values represent frequencies; $n=56$, multiple responses allowed but participants could abstain from ' $v$ oting'.

any case, engaging stakeholders and the public will be essential in identifying the most widely accepted and preferred water reuse solutions given that certain types of water re-use might not be appropriate due to cultural or social reasons, or lack of knowledge (see Table 3 ). To establish the use of both simple small-scale and more sophisticated large-scale water re-use and treatment technologies, the participants suggested that incentivising water re-use and enabling research and technology development and dissemination of this knowledge (see Table 3 ) are key to advancing sustainable water re-use in South Africa.

\section{General findings}

As part of an overall analysis of the data, participants' priorities were compared across the three themes. In the following section, the top consideration in each category (challenges, knowledge gaps, and solutions/recommendations) is highlighted for each theme, and commonalities across the three themes (Tables 1 to 3) are discussed for each category.

\section{Challenges}

The top 'challenge' in terms of 'public expectations and municipal obligations' was a lack of both skills and political will in government (Table 1). Similarly, in the area of 'water security and governance', restoring citizen trust in government intention and capability to deliver water-related services was the most significant challenge (Table 2). For 'water re-use-health and 
infrastructural considerations', the top challenge was failure to up-scale existing re-use technology proven to be successful at pilot scale (Table 3).

The relative importance of challenges across the three themes, indicated by 'votes' for the top challenge in each theme, showed that capacity and skills within the water sector were the greatest concern (Table 1, 24 votes); challenges in up-scaling technologies for re-use were next and of considerably less concern (Table 3, 11 votes), while restoring citizen trust (Table 2) received 7 votes.

Certain trends were evident across the challenges identified for the three themes:

- There were challenges relating to government policies, practices and transparency, at local (Municipal), regional and national levels.

- Public expectations of government (including municipalities) were unrealistic at times. Public trust in government institutions and level of satisfaction with service delivery were also low.

- Citizens often do not recognise their roles and responsibilities in ensuring a safe and adequate water supply, leading to a culture of dependency.

- There is a failure to translate research into policy and practice, and a lack of skills in leadership and technical positions. Also, loss of knowledge and expertise by movement of skills into the private sector or through emigration is a problem.

- Social issues such as rapid urbanisation and cultural perceptions of water re-use place pressure on water security and implementation of water facilities often do not adequately involve social and community structures.

- The start-up of new water ventures, engagement of all stakeholders in new water ventures, and capacity of courts to decide the merits of water-related cases all need to be enhanced.

\section{Knowledge gaps}

The top 'knowledge gaps' identified were understandings of the process and implications of the Green Drop and Blue Drop Programmes ('public expectations and municipal obligations', Table 1), knowledge transfer to the public (specifically referring to 'water re-use health and infrastructural considerations' in Table 3, but a recurrent concern across all three themes) and the role of educators ('water security and governance', Table 2, similar to Table 3 ).

Common trends in knowledge gaps identified across the three themes were as follows:

- The most prevalent knowledge gap, by far, relates to modes of knowledge dissemination. Problems in knowledge transfer were identified at all levels, including in national and local government (especially regarding the Blue Drop and Green Drop Programmes), academia, water consultancies and entrepreneurs, and even in schools.

- Understanding of human drivers of behaviour is needed in understanding how to stimulate water users to make positive changes in water-related behaviours.

- Health concerns were raised, particularly with respect to 'water re-use' (Table 3), but similar concerns were also expressed (although less explicitly) in relation to 'public expectations and municipal obligations' (Table 1) and 'water security and governance' (Table 2).

- Gaps in scientific and technological knowledge are delaying the implementation of water security interventions, particularly re-use implementations.

- Successful processes for resolving water-related conflicts between government and industries, and among industries themselves, are inadequate.

- There is insufficient engagement with, and regulation of, industries as one of the biggest users of water.

- Skills gaps in government restrict human interactions and leadership with regards to involving communities in decisions about water security, and promoting co-operation and transparency among government departments.

\section{Recommendations and solutions}

The top suggestions across the three themes were creating public awareness around and buy-in to initiatives to improve water security ('public expectations and municipal obligations', Table 1,23 votes), accessible and user-friendly conversion of research results to implementations ('water re-use and infrastructural considerations', Table 3, 10 votes) and ensuring an active role for educators in creating awareness around water security ('water security and governance, Table 2, 6 votes). As for challenges listed across the three themes, 'public expectations and municipal obligations was the area of greatest concern.

Common trends in recommendations/solutions across the three themes were as follows:

- Increasing the full-scale implementation of water re-use as a means of improving water security, and maximising the benefit from water as a limited resource-

- Facilitation of increased water re-use and efficient water use as a municipal/government obligation but, at the same time, a public responsibility

- Designing water and wastewater systems that work with the ecology of aquatic systems to improve water quality

- Generating a more holistic understanding of water security and its implications

- Improving the role of government, including improved governance, better leadership, integration of mandates and planning across different sectors to ensure that synergies are exploited

- Improving stakeholder participation, increasing investment in operation and maintenance, and encouraging shared ownership of water and sanitation infrastructure

- Improvement in education and human capacity-

- Technology should be more widely developed and implemented using innovation hubs and technology champions

\section{CONCLUDING REMARKS AND RECOMMENDATIONS}

Erratic weather patterns, particularly for rainfall, and, more recently, drought conditions in KwaZulu-Natal and other parts of South Africa, necessitate a paradigm shift to ensure 
that our water supply is sustainable. This requires a partnership between water services authorities and the end users. The World Economic Forum has in its Global Risk Report 2015 for the first time placed water crises at the top of the list of biggest global threats in terms of their potential impact, and re-categorised water crises to be a societal rather than solely an environmental risk. The findings of the focus group discussions reported on here suggest that attaining water security for all South Africans does not reside solely in scientific and technological developments but also in the role of government at all levels in effectively developing and implementing policies and in communicating these policies to the public. Pollution mitigation and water re-use will have to be practised routinely and deviation from such practices by any stakeholders will have to be addressed with strong resolve to ensure water security. One of the critical elements in ensuring that policy and mitigation strategies are followed is to share and disseminate knowledge timeously and meaningfully.

Some of the key recommendations emanating from the colloquium, ranked in decreasing order of significance, are presented in Table 4. Reference to these recommendations suggests that water security can best be attained by improving public and government awareness around water issues, and incentivising water re-use and conservation. The success of the latter will, however, demand an improved understanding of the health and social implications of water re-use and may even require measures such as rising block tariffs (in areas where they have not yet been adopted) as a means to incentivise responsible water use. Improved human capacity within the water sector and enhanced ecological infrastructure were perceived to be relatively less important than the recommendations mentioned above but will nevertheless be important in understanding water security within the country more holistically (for example, at the landscape and community levels; see Table 4).

All the processes that govern the attainment and maintenance of water security must be underpinned by strong partnerships between all stakeholders, who embrace the principles of sustainable development to secure this invaluable resource. However, the fact that water of appropriate quality is a limited and valuable resource, has not been sufficiently communicated in South Africa given the inadequate awareness in all quarters of society regarding the looming challenge of declining water security. The stakeholders present at the water security colloquium highlighted possible solutions and a way forward, and represent multipliers within civil society that are in a position to make a difference within their communities/sectors by increasing awareness towards a more responsible use of water.

\section{ACKNOWLEDGMENTS}

We thank the South African Young Academy of Science and the University of KwaZulu-Natal (School of Life Sciences, Westville Campus) for supporting the colloquium at which this study was conducted.

\section{REFERENCES}

BUYTAERT W, ZULKKAFLI Z, GRAINGER S, ACOSTA L, ALEMIE TC, BASTIAENSEN J, DE BIÈVRE B, BHUSAL J, CLARK J, DEWULF A, FOGGIN M, HANNAH DM, HERGARTEN C, ISAEVA A, KARPOUZOGLOU T, PANDEYAB, PAUDEL D, SHARMA K, STEENHUIS T, TILAHUN S, VAN HECKEN G and ZHUMANOVA M (2014) Citizen science in hydrology and water resources: opportunities for knowledge generation, ecosystem service management, and sustainable development. Front. Earth Sci. 2 1-21. http://dx.doi.org/10.3389/feart.2014.00026

\begin{tabular}{|l|c|}
\hline \multicolumn{2}{|c|}{ TABLE 4 } \\
$\begin{array}{l}|c| \\
\text { Ranking of overall recommendations for ensuring water } \\
\text { security by colloquium participants; listed in decreasing } \\
\text { order of importance }\end{array}$ \\
\hline Recommendation & Frequency* \\
\hline $\begin{array}{l}\text { Improve public and government awareness around } \\
\text { water issues }\end{array}$ & 26 \\
\hline Incentivise water re-use and conservation & 16 \\
\hline Introduce rising block tariffs & 15 \\
\hline $\begin{array}{l}\text { Improve understanding of health and social implica- } \\
\text { tions of water re-use }\end{array}$ & 15 \\
\hline Improve human capacity development in water sector & 13 \\
\hline Enhance ecological infrastructure & 11 \\
\hline $\begin{array}{l}\text { Define water security in the context of geography and } \\
\text { human demographics }\end{array}$ & 9 \\
\hline $\begin{array}{l}\text { Strengthen interaction and alliances among } \\
\text { stakeholders }\end{array}$ & 8 \\
\hline
\end{tabular}

${ }^{*}$ Values represent frequencies; $n=56$, multiple responses allowed but participants could abstain from 'voting'.

COETZEE H, HOBBS PJ, BURGESS JE, THOMAS A, KEET M, YIBAS B, VAN TONDER D, NETILI F, RUST V, WADE P and MAREE J (2010) Mine water management in the Witwatersrand gold fields with special emphasis on acid mine drainage. Report to the Inter-Ministerial Committee on acid mine drainage. Council for Geoscience, Pretoria.

COLLIGNON B and VÉZINA M (2000) Independent water and sanitation providers in African cities. World Bank, Water and Sanitation Program, Washington, DC.

DAY C, GRAY A and BUDGELL E (2011) Health and related indicators. S. Afr. Health Rev. 17 207-329.

D’EATHE L (2014) Personal communication, 4 June 2015. Mr Lee D'Eather, Palmiet River Watch, Westville, Durban.

DENT MC (2012) Catchment management agencies as crucibles in which to develop responsible leaders in South Africa. Water SA 38 (2) 313-326. http://dx.doi.org/10.4314/wsa.v38i2.17

DWA (DEPARTMENT OF WATER AFFAIRS, SOUTH AFRICA) (2010) Blue Drop Report: South African drinking water quality management performance. Republic of South Africa. URL: https://www.dwaf.gov. za/Documents/blueDrop.pdf (Accessed 16 July 2015).

DWA (DEPARTMENT OF WATER AFFAIRS, SOUTH AFRICA) (2013a) Green Drop Report: Municipal and private wastewater systems. URL: https://www.dwa.gov.za/Documents/Executive\%20 Summary\%20for\%20the\%202013\%20Green\%20Drop\%20Report.pdf (Accessed 16 July 2015).

DWA (DEPARTMENT OF WATER AFFAIRS, SOUTH AFRICA) (2013b) Blue Drop Report Handbook: Progress Report. Republic of South Africa. URL: https://www.dwa.gov.za/Documents/BD/ BDIntro.pdf (Accessed 16 July 2015).

DWA (DEPARTMENT OF WATER AFFAIRS, SOUTH AFRICA) (2013c) Blue Drop progress report \& national Blue Drop risk-rating - the regulatory impression. URL: https://www.dwaf.gov.za/dir_ws/DWQR/ subscr/ViewComDoc.asp?Docid=674 (Accessed 16 July 2015).

DWAF (DEPARTMENT OF WATER AFFAIRS AND FORESTRY, SOUTH AFRICA) (1997) White paper on a national water policy for South Africa. Republic of South Africa. URL: https://www.dwa.gov. za/Documents/Policies/nwpwp.pdf (Accessed 16 July 2015).

DWAF (DEPARTMENT OF WATER AFFAIRS AND FORESTRY, SOUTH AFRICA) (2005) Drinking water quality management guide for water services authorities. September 2005. URL: https://www. dwaf.gov.za/Documents/Other/DWQM/DWQMWSAGuideSept05. pdf (Accessed 16 July 2015).

FINK G, GÜNTHER I and HILL K (2011) The effect of water and sanitation on child health: evidence from the demographic and health surveys 1986-2007. Int. J. Epidemiol. 40 (5) 1196-1204. http://dx.doi. org/10.1093/ije/dyr102 
GERLAND P, RAFTERY AE, ŠEVČIKOVĂ H, LI N, GU D, SPOORENBERG T, ALKEMA L, FOSDICK BK, CHUNN J, LALIC N, BAY G, BUETTNER T, HEILIG GK and WILMOTH J (2014) World population stabilization unlikely this century. Science 346 (6206) 234-237. http://dx.doi.org/10.1126/science.1257469

GHUNMI LA, ZEEMAN G, FAYYAD M and VAN LIER JB (2011) Grey water treatment systems: A review. Crit. Rev. Environ. Sci. Technol. 41 (7) 657-698. http://dx.doi.org/10.1080/10643380903048443

GREY D and SADOFF CW (2007) Sink or Swim? Water security for growth and development Water Polic. 9 (6) 545-571.

GEMMELL ME and SCHMIDT S (2013) Is the microbiological quality of the Msunduzi River (KwaZulu-Natal, South Africa) suitable for domestic, recreational, and agricultural purposes? Environ. Sci. Pollut. Res. 20 6551-6562. http://dx.doi.org/10.1007/ s11356-013-1710-1

HARDBERGER A (2005) Life, liberty, and the pursuit of water: evaluating water as a human right and the duties and obligations it creates. Northwestern Univ. J. Int. Hum. Rights 4 (2) 331-362. http://dx.doi. org/10.2139/ssrn.1873998

HEIJNEN M, CUMMING O, PELETZ R, CHAN GKS, BROWN J, NAKER K and CLASEN T (2014) Shared sanitation versus individual household latrines: A systematic review of health outcomes. PLoS ONE 9 (4) e93300. http://dx.doi.org/10.1371/journal.pone.0093300

HOEKSTRA AY and CHAPAGAIN AK (2007) Water footprints of nations: Water use by people as a function of their consumption pattern. Water Resour. Manage. 21 (1) 35-48. http://dx.doi. org/10.1002/9780470696224.ch5

HOEKSTRA AY and MEKONNEN MM (2012) The water footprint of humanity. Proc. Natl. Acad. Sci. 109 (9) 3232-3237. http://dx.doi. org/10.1073/pnas.1109936109

HRC (HUMAN RIGHTS COMMISSION, SOUTH AFRICA) (2014) Report on the right to access sufficient water and decent sanitation in South Africa: 2014. Human Rights Commission, Johannesburg. URL: www.sahrc.org.za/home/21/files/FINAL\%204th\%20Proof\%204\%20 March\%20-\%20Water\%20\%20Sanitation\%20low\%20res\%20(2).pdf (Accessed 06 June 2016).

MATANGO S, BIRUNGI G, MOODLEY B and NDUNGU P (2015) Occurrence of selected pharmaceuticals in water and sediment of Umgeni River, KwaZulu-Natal, South Africa. Environ. Sci. Pollut. Res. 22 10298-10308. http://dx.doi.org/10.1007/s11356-015-4217-0

NOWOTNY H, SCOTT P and GIBBONS M (2001) Re-thinking science: Knowledge and the public in an age of uncertainty. Polity, Cambridge.

NYENJE PM, FOPPEN JW, UHLENBROOK S, KULABAKO R and MUWANGA A (2010) Eutrophication and nutrient release in urban areas of sub-Saharan Africa - a review. Sci. Total Environ. 408 (3) 447-455. http://dx.doi.org/10.1016/j.scitotenv.2009.10.020

OPEN SCIENTIST (2011) Finalizing a Definition of 'Citizen Science' and 'Citizen Scientists'. URL: http://www.openscientist.org/2011/09/ finalizing-definition-of-citizen.html (Accessed 21 February 2015).

PHEIFFER W, PIETERS R, VAN DYK JC and SMIT NJ (2014) Metal contamination of sediments and fish from the Vaal River, South Africa. Afr. J. Aquat. Sci. 39 (1) 117-121. http://dx.doi.org/10.2989/16 085914.2013.854732

POWELL RA and SINGLE HM (1996) Focus groups. Int. J. Qual. Health Care 8 (5) 499-504. http://dx.doi.org/10.1093/intqhe/8.5.499

RSA (REPUBLIC OF SOUTH AFRICA) (1997) Water Services Act: Act No. 108 of 1997. Government Gazette 18522. Government Printer, Cape Town.

RODDA N, CARDEN K, ARMITAGE N and DU PLESSIS HM (2011) Development of guidance for sustainable irrigation use of greywater in gardens and small-scale agriculture in South Africa. Water SA 37 (5) 727-737. http://dx.doi.org/10.4314/wsa.v37i5.10

SABS (SOUTH AFRCIAN BUREAU OF STANDARDS) (2006) SANS 241 Drinking Water Standard. South African National Standard (SANS). South African Bureau of Standards, Pretoria. URL: http://www.alabbott.co.za/docs/2985_SANS-241_spec.pdf(Accessed 16 July 2015).
SAICE (SOUTH AFRICAN INSTITUTION OF CIVIL ENGINEERING) (2011) SAICE Infrastructure Report Card for South Africa 2011. URL: http://www.csir.co.za/enews/2011_jun/download/infrastructure_report_card_sa_2011.pdf (Accessed 16 July 2015).

SCHARMER CO (2009) Leadership development is not about filling a gap but about igniting a field of inspired connection and action: Ten propositions on transforming the current leadership development paradigm. In: Round Table Meeting on Leadership for Development Impact. The World Bank Institute, Washington DC. 27-28.

SIEBRITS RM, WINTER K, BARNES J, DENT MC, EKAMA G, GINSTER M, HARRISON J, JACKSON B, JACOBS I, JORDAAN A and KASAN HC (2014) Priority water research questions for South Africa developed through participatory processes. Water SA $\mathbf{4 0}$ (2) 199-210. http://dx.doi.org/10.4314/wsa.v40i2.2

STATISTICS SOUTH AFRICA (2012) Census 2011. Stats SA, Pretoria.

UNICEF and WHO (UNITED NATIONS CHILDREN'S FUND and WORLD HEALTH ORGANIZATION) (2015) Progress on Sanitation and Drinking Water: 2015 Update and MDG Assessment. URL: http://www.unicef.org/publications/files/Progress on Sanitation_and_Drinking_Water_2015_Update_.pdf (Accessed 16 July 2015).

UNEP/WHO (UNITED NATIONS ENVIRONMENT PROGRAMME/ WORLD HEALTH ORGANIZATION) (2013) Africa Environment Outlook 3. Summary for Policy Makers. UNEP/WHO. URL: http:// www.unep.org/pdf/aeo3.pdf (Accessed 16 July 2015).

VALIPOUR M (2015) Land use policy and agricultural water management of the previous half of century in Africa. Appl. Water Sci. 5 (4) 367-395. http://dx.doi.org/10.1007/s13201-014-0199-1

VÖRÖSMARTY CJ, DOUGLAS EM, GREEN PA and REVENGA C (2005) Geospatial indicators of emerging water stress: an application to Africa. AMBIO 34 (3) 230-236. http://dx.doi org/10.1579/0044-7447-34.3.230

VÖRÖSMARTY CJ, MCINTYRE PB, GESSNER MO, DUDGEON D, PRUSEVICH A, GREEN P, GLIDDEN S, BUNN SE, SULLIVAN CA, REIDY LIERMANN C and DAVIES PM (2010) Global threats to human water security and river biodiversity. Nature $\mathbf{4 6 7}$ (7315) 555-561. http://dx.doi.org/10.1038/nature09440

WALS AEJ, BRODY M, DILLON J and STEVENSON RB (2014) Convergence between science and environmental education. Science 344 (6184) 583-584. http://dx.doi.org/10.1126/science.1250515

WEIN A and LABIOSA W (2013) Serious games experiment toward agent-based simulation. U.S. Geological Survey Open File Report 2013-1152. USGS, Washington DC. URL: http://pubs.usgs.gov/ of/2013/1152/pdf/ofr20131152.pdf (Accessed 16 July 2015).

WEITZ N, NILSSON M and DAVIS M (2014) A nexus approach to the post-2015 agenda: Formulating integrated water, energy, and food SDGs. SAIS Rev. Int. Affairs 34 (2) 37-50. http://dx.doi.org/10.1353/ sais.2014.0022

WHO (2015) Sanitation safety planning: manual for safe use and disposal of wastewater, greywater and excreta. WHO, Geneva. URL: http:// apps.who.int/iris/bitstream/10665/171753/1/9789241549240_eng. pdf?ua $=1$ (Accessed 16 July 2015).

WESSA (WILDLIFE AND ENVIRONMENT SOCIETY OF SOUTH AFRICA) (2012) South Africa's Water Resources: WESSA Position Statement. URL: http://wessa.org.za/uploads/images/positionstatements/Water\%20Resources\%20-\%20WESSA\%20Position\%20 Statement\%20-\%20Approved\%202013\%20.pdf (Accessed 16 July 2015).

WORLD ECONOMIC FORUM (2015) Global Risk 2015. URL: http:// www3.weforum.org/docs/WEF_Global_Risks 2015_Report15.pdf (Accessed 16 July 2015). 